\title{
INTERNATIONALIZATION AND LANGUAGE POLICIES IN BRAZIL: EVIDENCE OF THE INTERFACE AT UFES
}

\author{
INTERNACIONALIZAÇÃO E POLÍTICAS LINGUÍSTICAS NO BRASIL: \\ EVIDÊNCIAS DA INTERFACE NA UFES
}

\author{
Felipe Furtado Guimarães ${ }^{1}$, Kyria Rebeca Finardi ${ }^{2}$
}

\begin{abstract}
This paper discusses the interface between internationalization and language policies in general in Brazil by looking for evidence and traces of evidence in a local context. More specifically, Brazilian national programs such as the Science without Borders (SwB), the Languages without Borders ( LwB) and the Capes PrInt call are analysed in the national context, as evidence of national policies. Then, the analysis and discussion zooms in a local context to find evidence of these policies in the recently approved internationalization and language policies of the Federal University of Espirito Santo (UFES) located in the Southeast of Brazil. Overall the analysis concludes that UFES internationalization and language policies are related and aligned with national policies having been induced by them in a reactive way.
\end{abstract}

KEYWORDS: internationalization; language policies; UFES.

RESUMO: Este estudo discute a interface entre internacionalização e políticas linguísticas em geral no Brasil, buscando por evidências e indicios em um contexto local. Mais especificamente, programas nacionais brasileiros como o Ciência sem Fronteiras (CsF), Idiomas sem Fronteiras (IsF) e o Edital Capes PrInt são analisados no contexto nacional, como evidências de políticas nacionais. Então a análise e a discussão seguem para o contexto local, de forma a encontrar evidências dessas politicas nas políticas linguísticas e de internacionalização, aprovadas recentemente na Universidade Federal do Espírito Santo (UFES), localizada no Sudeste brasileiro. Em geral, a análise conclui que as políticas linguísticas e de internacionalização da UFES estão relacionadas e alinhadas a políticas nacionais tendo sido induzidas por elas de forma reativa.

PALAVRAS-CHAVE: internacionalização; políticas linguísticas; UFES.

\footnotetext{
${ }^{1}$ Doutorando no Programa de Pós-Graduação em Linguística (PPGEL) da Universidade Federal do Espírito Santo (UFES).

${ }^{2}$ Professora no Departamento de Linguagens, Cultura e Educação (DLCE) da Universidade Federal do Espírito Santo (UFES) e nos programas de Pós-Graduação em Linguística (PPGEL) e em Educação (PPGE) na UFES.
} 


\section{Introduction}

Despite being discussed only recently in Brazil, due to government-funded programs such as the Science without Borders $(\mathrm{SwB})^{3}$, Languages without Borders $(\mathrm{LwB})^{4}$ and the Capes PrInt ${ }^{5}$ call (GUIMARÃES; FINARDI; CASOTTI, 2019), internationalization is not a new phenomenon worldwide. It is such an important process that Laus (2012) states that it has become an "unequivocal reality", because of a growing interdependence of countries (REPPOLD FILHO; TORRES e CARDOSO; VAZ, 2010) in various fields of knowledge.

Higher education had internationalization components since the advent of the first European schools known as universitas (STALLIVIERI, 2014). Such schools had professors and students from various regions, who got together to produce knowledge, through the collaboration between scholars from different fields of research and countries. Since its foundation, centuries ago, the institution known as "university" was based on the free flow of ideas within a diverse academic community, using debates for teaching/learning (AKKARI, 2018).

Berlinck (2013) states that the concept of universitas did not mean that there was a university built in a given place - the wish of professors and students to study was enough to establish a place for teaching/learning, even if that place was temporary. He adds that the first universitas which became an institution similar to modern universities was Bologna, in 1088, followed by Paris (1170). Teichler (2003) adds that students and staff members of the first European universities used academic mobility to be in regions where a higher level of education was available.

Bologna is known not only for hosting the first established university, but also for being the place where the European resolution to harmonize education in the region was signed in 1999. The Bologna Process formed the European Higher Education Area ${ }^{6}$, made up of the 27 countries from the European Community and other European countries such as

\footnotetext{
${ }^{3}$ Internationalization program that offered scholarships for Brazilian university students (mainly at undergraduate level) to study abroad. It is also considered the largest Brazilian academic mobility plan, launched in 2011 and discontinued in 2016.

${ }^{4}$ Internationalization and languages program launched in 2012 as English without Borders, renamed Languages without Borders in 2014, to include other languages besides English. The program offers language courses (both online and face-to-face) and proficiency tests free of charge, for the academic community of partner higher education institutions. More information at: http://isf.mec.gov.br/

${ }^{5}$ Internationalization program launched after the discontinuity of the SwB and focused on the graduate level. Capes is the Coordination for Development of Higher education Personnel, an agency of the Ministry of Education. More information at: http://www.capes.gov.br/cooperacao-internacional/multinacional/programa-institucional-de-internacionalizacao-capes-print

${ }^{6}$ More information at: http://www.ehea.info/
} 
Serbia and European-Asian countries like Turkey and Russia. The Bologna Process represents an attempt to share the leadership of the internationalization process worldwide with the USA and is mentioned here because it has strongly affected the process of internationalization in Latin America (MENEGHEL, CAMARGO; SPELLER, 2018).

According to Lincoln Bizzozero (in MENEGHEL, CAMARGO; SPELLER, 2018, p.15), the two events that most affected the internationalization of higher education in the XXI century were the attempt by the World Trade Organization (WTO) to include higher education in the General Agreement on Trade in Services (GATS), and the second was the Bologna Process. WTO's view suggests that education can have strong bonds with economy, and the inclusion of education among the services ruled by GATS indicates a perspective of commodification of education at a global level, allowing the participation of foreign stakeholders in the provision of educational services nationwide (RIBEIRO, 2006).

In Latin America in general and in Brazil in particular, this tendency can be seen in the first actions of the recently elected right-wing president Jair Bolsonaro. The view of education as commodification or as an accountable business is evident in the movement of the central government towards countries like Chile (and the USA in North America) and away from countries such as Venezuela and Bolivia. The movement for free access to higher education in Chile which began with left-wing ex-president Bachelet seems to have regressed with the election of current right-wing president Piñera. Whatever the case, it is evident that the processes of internationalization and transnationalization of higher education in Latin America are greatly affected by these processes in Europe and in the USA (MENEGHEL, CAMARGO; SPELLER, 2018).

Bernheim (2018) claims that globalization affects countries in different ways and though it is associated with internationalization, it cannot be confused with it. Whereas the former is conceptualized as the free flow of technologies, economy, values and people through borders, the latter is an institutional response to the impacts of globalization in a local context. The author also distinguishes between the concepts of internationalization and transnationalization of higher education. Whereas the former is aligned with the goals of the World Declaration on Higher Education to establish solidary (and horizontal) international cooperation based on intercultural dialogue respecting the local contexts and identities of participants, the latter is related to an international cooperation dominated by power (and 
vertical) relations that view education as a service subject to the market with a predominance of commercial interests.

According to Dias (2017), a series of apparently independent, but in fact interrelated, events consolidated the process of internationalization of higher education (IHE) as we know now. There is a hegemony of a small group of countries, most of which are from the Global North $^{7}$ (SANTOS, 2011) and speak English or adopted English as the medium of instruction EMI (for example, FINARDI; SANTOS; GUIMARÃES, 2016).

As a result of this hegemony in the process of internationalization, countries in the Global South import internationalization models (and rankings) in an uncritical way (FINARDI; GUIMARÃES, 2017b). One consequence of the use of these models in countries of the Global South is that internationalization is conceived and practiced in a way that benefits more the North than the South (VAVRUS; PEKOL, 2015).

The events mentioned by Dias (2017) are: 1) the consolidation of GATS with higher education as part of it; 2) the review of the international accreditation system; 3) the Bologna Process; 4) the development of massive online open courses (MOOCs); and 5) the classification system of rankings based on criteria adopted mostly by hegemonic countries.

In the case of MOOCs, Finardi and Tyler (2015) analyzed the role of English in the process of internationalization and in the offer of MOOCs. These authors analyzed the offer of MOOCs in terms of language and contents in the most important MOOC platforms. Results of that study showed that $83 \%$ of the courses were offered in English only, showing a language hegemony and a relation between language and internationalization (or in some cases, transnationalization of education).

That relation also became evident in the analysis of courses offered in English (English Medium Instruction - EMI) in Taquini, Finardi and Amorim (2017) who analyzed the offer of EMI courses in Turkey, when that country was attempting to adapt to the Bologna Process as a condition to enter the European Community. The analysis contrasted the situation in Turkey and in Brazil (two developing countries that share many similarities) and concluded that there are both benefits and hurdles to the adoption of EMI courses in developing countries. Martinez (2016) had reached a similar conclusion about the EMI offer in Brazil a year earlier.

\footnotetext{
${ }^{7}$ Boaventura de Sousa Santos uses this term to refer to central/hegemonic countries, despite their geographical location, since this is a geopolitical term.
} 
Nowadays many universities, when seeking for external funding, sell courses/programs as products and see cooperation as a type of trade (which is why higher education "products and services" were included in the GATS). This process forces developing countries to adapt their educational systems so as to mirror the Bologna process which, in turn, is an adaptation of the North American model adopted in the USA since the 1950’s.

In the following sections, we discuss global trends that affected Brazilian internationalization and language policies, in order to connect the elements in such policies, with the purpose of analyzing internationalization and language policies in a local context, namely, that of a federal university in the Southeast part of Brazil, through two insiders' perspectives.

\section{Internationalization and language policies}

As stated before in this study, internationalization is not a new phenomenon, but only recently, it has become an object of systematic study, by various authors around the world (for example, KNIGHT, 1994; ALTBACH; KNIGHT, 2007; HUDZIK, 2011; DE WIT, 2011a; BEELEN; JONES, 2015), in Brazil (for example, LIMA; MARANHÃO, 2009; LAUS, 2012; FINARDI; PORCINO, 2014; STALLIVIERI, 2014; BAUMVOL; SARMENTO, 2016; FINARDI; GUIMARÃES, 2017a; MOROSINI; CORTE, 2018; GUIMARÃES; FINARDI, 2018) and in the state of Espirito Santo, more specifically, at the Federal University of Espirito Santo - UFES, the focus of the present study (for example, FINARDI; ORTIZ, 2015; FINARDI; SANTOS; GUIMARÃES, 2016; AMORIM; FINARDI, 2017). For a broader public, such process started some 30 years ago (DE WIT, 2016).

Although the number of studies around internationalization has increased recently, there is still some confusion around this process, leading to misconceptions (DE WIT, 2011b) and myths (KNIGHT, 2011). The misconceptions indicated by De Wit (2011b, p. 6) are ideas that people usually associate with internationalization "where the means appear to have become the goal". The myths described by Knight (2011) are implicit assumptions that people developed about internationalization. 
Some of the misconceptions relate internationalization to: a) education in the English language; b) studying or staying abroad; c) international subjects in the curriculum (training based on international contents, such as a course on "European studies"); d) having many international students; e) no need to test/develop intercultural and international competencies (as if students could normally acquire these skills abroad or in local classes with foreign classmates); f) the more partnerships, the more international; g) higher education is international by nature (no need to stimulate and guide the internationalization).

The myths relate internationalization to: a) foreign students as internationalization agents (although many of them feel marginalized and experience ethnic tensions); b) international reputation as proxy for quality (the more international a university is, the better its reputation); c) international institutional agreements (the greater number of agreements, the more prestigious) - this is similar to misconception " $\mathrm{f}$ " above; $\mathrm{d}$ ) international accreditation (from quality assurance agencies); e) global branding (the purpose of the internationalization efforts is to improve visibility in the international scenario).

In the midst of such misconceptions and myths, we recall one of the most known definitions of internationalization given by Knight (2003): "Internationalization [...] is defined as the process of integrating an international, intercultural, or global dimension into the purpose, functions or delivery of postsecondary education". In what relates to the Brazilian scenario, Finardi (2016a, 2016b, 2016c) and Guimarães, Finardi and Casotti (2019) consider that evidence of internationalization and language policies can be found in national programs such as the Sciences Without Borders (SwB), the Languages Without Borders (LwB) and the Capes PrInt.

The view of internationalization explicit in these programs can be associated with an implicit internationalization policy. In the case of the $\mathrm{SwB}$, it equated internationalization with outgoing academic mobility (mostly for undergraduate level) and because of the criticism that this program received, the Capes PrInt was proposed for graduate level, but still mostly for outgoing academic mobility. As such, both the SwB and the Capes PrInt seem to implicitly equate internationalization mainly with outgoing academic mobility.

According to Finardi and Archanjo (2018), the LwB can be considered an implicit language policy and was created as a result of the lack of proficiency (mostly in English) of candidates of the SwB. Another evidence of language policy found in these programs is the mention by Capes that proposals for the PrInt call must be made in English. Still in what 
regards the Capes PrInt call, we can find another trace of internationalization policy in the view of internationalization and the list of countries available for cooperation. The Capes PrInt call lists 26 priority countries (for partnerships and outgoing academic mobility), 15 of which are in Europe and 2 in North America, with only 4 countries in the Southern Hemisphere, though 2 of these are in the Global North (SANTOS, 2011).

In regards to language policies (LPs) in general, Ricento (2006) states that languages play different roles in different settings - that is, defining policies should take into account the environment where languages are used and their users. Shohamy (2006) indicates that LPs take place in battlefields where there is a clash between language ideologies and practices. Spolsky (2004) points out that LPs encompass a variety of factors: social, political, economic, religious, demographic, educational and cultural. Thus LPs are represented in overt and covert mechanisms (SHOHAMY, 2006) and instruments, used to put into practice the beliefs about language of certain groups in a given society.

Regarding language policies for higher education, there is no explicit policy for foreign languages in Brazil. However, that has changed dramatically in the last decade, due to the increasing internationalization of Brazilian institutions with public investment in mobility programs such as the $\mathrm{SwB}$, the LwB and the Capes PrInt. Although the SwB was discontinued in 2015, the LwB is still going strong and is funded by the Brazilian government, having recently induced the creation of language policies for internationalization in its member-institutions, UFES being one example. Indeed, the language policy at UFES was promulgated so as to meet the requirements of the LwB call and were it not for this program perhaps UFES would not have an official language policy approved by its board now.

Much in the same way, the Capes PrInt call induced universities to approve an institutional internationalization policy or plan, so as to submit proposals for the call. Several higher education institutions (HEIs) submitted their proposals for funding but only 25 universities were selected to receive funding, among which is UFES. The Capes-PrInt call had an inductive nature and required candidate institutions to formalize internationalization policies, much in the same way that the LwB program had previously done one year earlier, specifically for language policies.

Since the PrInt and the LwB are both financed by Capes, it goes without saying that both programs are aligned with Capes view of internationalization (as being mostly carried out through academic mobility) and languages for internationalization (with English being the 
most prominent). Evidence of this view can be found in the financing for academic mobility of the PrInt call and in the financing to English (only) in the LwB program.

Moreover, if we analyze the role of English in these programs and calls, it is possible to see a globalization trend that recognizes the hegemonic force of some countries (the 26 listed in the PrInt call) and languages (English, for Capes). In the case of the LwB program, for example, though the program offers free activities (face-to-face courses, proficiency tests and online courses) in many languages, Capes finances scholarships only for English.

As a result, the number of courses in English is much larger than the courses/actions for other languages which depend on local institutional financing. The fact that Capes through the LwB finances only English has raised strong criticism towards the program on the grounds that it remains "English without Borders" even though the name was changed to "Languages without Borders" in 2014.

Considering that UFES recently approved its internationalization plan and language policy, it is possible to claim that both the LwB and the Capes-PrInt call had a strong (inductive) influence in these documents. After much negotiation, UFES internationalization and language policies were able to include other countries and languages in these policies, but the resistance to Capes' view of internationalization (as being mostly carried out through academic mobility and partnerships with those countries listed as priority) and languages (English being the most important one) remains despite the overruling force of the central administration. To describe this process, the next section explains the method used to analyse the internationalization and language policies at UFES.

\section{Method}

As stated at the outset of this paper, the aim of this study is to analyse the influence of national policies embedded in programs like the SwB, the LwB and the Capes PrInt in local policies. More specifically, the study aims to analyse the influence of national policies covert in programs like the $\mathrm{SwB}$, the $\mathrm{LwB}$ and the Capes PrInt in the internationalization and language policies of a federal university in the Southeast region of Brazil.

So as to achieve this goal, the study qualitatively analyzed the recently approved internationalization plan and language policy of the Federal University of Espirito Santo 
(UFES) and later contrasted this analysis with the review of Brazilian internationalization and language policies implicit in internationalization programs such as the Swb, the LwB and the Capes PrInt.

Data comes from two sources. The first is the internationalization and language policies texts approved by UFES board and the second is the analysis of two members of the international office (IO). The analysis of the texts was carried out using a software that forms word clouds based on pre-defined criteria. The word clouds generated with the internationalization plan and language policy texts approved at UFES were then qualitatively analysed through two insiders' perspectives on the negotiations carried out during the proposal and approval of these documents at UFES. The authors of this paper work in the Language Division of UFES/IO and were actively involved in the discussions and elaboration of these documents, providing insiders' perspectives in the analysis.

\subsection{UFES}

Founded in 1954, UFES is the only federal university in the state of Espirito Santo and has 4 campuses spread across 3 cities in the state of Espirito Santo, in the Southeastern region of Brazil. With around 100 undergraduate courses, 60 graduate courses, 25,000 students, and 4,000 staff members (faculty and administrative staff), it is a medium-sized university in Brazilian standards. In relation to its research and outreach activities, UFES has around 600 ongoing projects, serving 1,5 million people. Its most prominent fields of research are: astrophysics, biotechnology, education, environmental engineering, infectious diseases, public health and social policy.

\section{Analysis}

As previously mentioned, UFES has recently approved an internationalization plan $(\mathrm{IP})^{8}$ and a language policy (LP) ${ }^{9}$ for internationalization, as part of the requirement for

\footnotetext{
${ }^{8}$ More information at:

http://www.internacional.ufes.br/sites/internacional.ufes.br/files/field/anexo/resolucao_no_15.2018_-_sri_-_politica_instituci onal_de_internacionalizacao_1.pdf

${ }^{9}$ More information at:

http://www.daocs.ufes.br/sites/daocs.ufes.br/files/field/anexo/ilovepdf_merged_0.pdf\#overlay-context=resolu\%25C3\%25A7 $\% 25$ C3\%25B5es-de-2018-cepe
} 
submitting a proposal for the Capes PrInt call and for being a member-institution of the LwB program, respectively. UFES language policy resolution was hotly debated in the university community and boards and only came into action after a series of negotiations between the central administration and the language and education departments, which strongly opposed the policy because of its "internationalization" nature, threatening, according to their view, local identities and languages.

Those who defended this view (of threat) suggested that the policy should include a role for LIBRAS (Brazilian sign language), indigenous languages and other foreign languages in the text. In the end, the will of the central administration prevailed (not before a long political negotiation) and mentions to these languages were removed from the document. The resolution approved by the UFES board does not make any mention to LIBRAS or any indigenous or minority language thus making it implicit that UFES is aligned with LwB and Capes views of the hegemonic language (English) for internationalization.

So as to visually aid the analysis of such documents (IP and LP), a website ${ }^{10}$ that creates "word clouds" (or tag cloud) ${ }^{11}$ based on the frequency in which words appear in these documents (written in Brazilian Portuguese) was used. Words such as articles, numbers and connectors (which are more frequent than nouns) were removed from the general word list, in order to find a pattern in terms of frequency of more relevant words. Figure 1 shows the most frequent words in the IP.

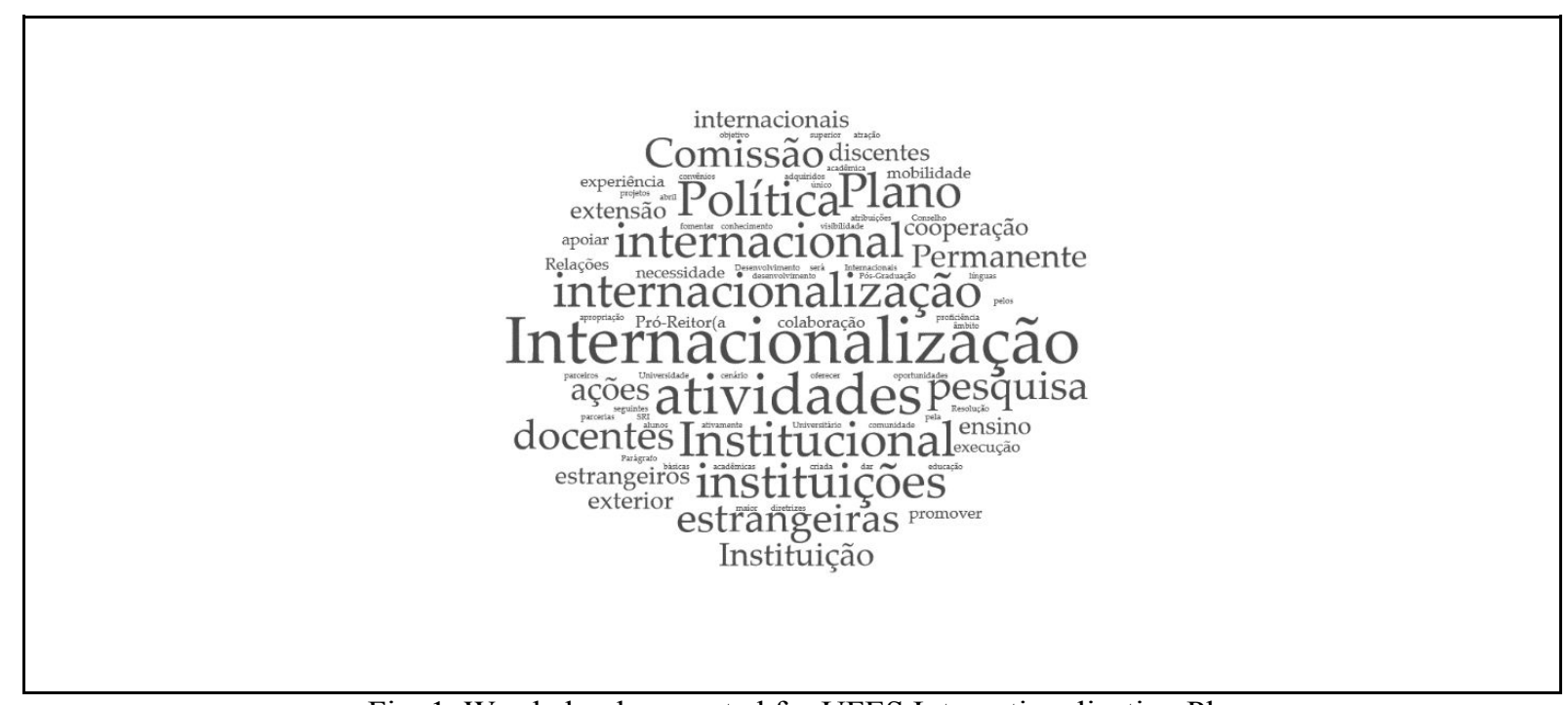

Fig. 1. Word cloud generated for UFES Internationalization Plan

\footnotetext{
${ }^{10}$ More information at: https://www.wordclouds.com/

${ }^{11}$ In Visual Design, it means a weighed list.
} 
In the internationalization plan (IP), the words/expressions (translated here to English) that we think are worth highlighting here are: permanent commission; activities; research; and foreign institutions. This list of words suggests that UFES Internationalization Permanent Commission $^{12}$ (IPC), composed by professors with a large internationalization experience, has an important role in the definition of the institutional internationalization policy. UFES faculty is of around 1,800 professors, only about 15 of whom are part of the IPC, representing less than $1 \%$ of the faculty who have a saying in the institutional internationalization plan. This is important for it shows that the UFES IP was approved in a top-down way and, we argue, also as a reaction towards the PrInt call that required an approved IP to submit proposals.

The word "activities" indicates a view of internationalization based on actions/activities such as sending students abroad and establishing agreements, as discussed by Knight (2005). Though the word activity may be (wrongly) interpreted as relating to "action", a deeper analysis of internationalization actions, programs and plans at UFES shows that in fact, most of the internationalization actions/activities at UFES are proposed in a reactive way (AMORIM; FINARDI, 2017; FINARDI; GUIMARÃES, 2017b; GUIMARÃES; FINARDI; CASOTTI, 2019), one exception being the creation of the Language Division of the IO, described in Finardi, Santos and Guimarães (2016).

Finardi and Ortiz (2015) analyzed some internationalization programs at UFES concluding that the institution was more focused on sending academics abroad with programs such as the SwB, than on developing an active internationalization (LIMA; MARANHÃO, 2009) to receive international students through programs such as PEC-G ${ }^{13}$ and PEC-PG ${ }^{14}$.

The word "research" indicates that UFES is considering one of the key components for Internationalization at Home $(\mathrm{IaH})^{15}$ and abroad (KNIGHT, 2005). Yet, the focus on research (carried out mainly in graduate programs) only came as a reaction to the Capes PrInt call. Indeed, between 2011 and 2016, when SwB was active and the Capes PrInt had not replaced it yet, most of the outgoing mobility was done with the SwB program (at

\footnotetext{
${ }^{12}$ More information at:

http://www.ufes.br/conteudo/comiss\%C3\%A3o-permanente-de-internacionaliza\%C3\%A7\%C3\%A3o-tem-novos-membros

${ }^{13}$ More information at: http://www.dce.mre.gov.br/PEC/PECG.php

${ }^{14}$ More information at: http://www.dce.mre.gov.br/PEC/PECPG.php

${ }^{15}$ Concept improved by Beelen and Jones (2015, p. 69) defined as the "purposeful integration of international and intercultural dimensions into the formal and informal curriculum, for all students within domestic learning environments".
} 
undergraduate level) and so the focus of the international office (and plan) was much more on undergraduate level (mobility) than on graduate level. Evidence of this is the fact that the former SwB coordinator at UFES gained so much prominence with that program during the period in which it was active, that she was appointed the international secretary in that institution.

Another piece of evidence can be found in the fact that the secretary of the IO (ex-coordinator of the SwB at UFES) worked together with the language coordinator in the creation of the IO as it is now. While the former is an engineer, the latter comes from the language/education areas. As previously mentioned, the $\mathrm{SwB}$ was targeted at specific areas (mostly from $\mathrm{STEM}^{16}$ areas) that did not include language/education (FINARDI; LEÃO; PINHEIRO, 2016) and so, most of the academic mobility at UFES (prior to PrInt) was outgoing through the SwB program. As such, outgoing mobility and STEM areas were "equated" with internationalization views/actions at UFES and areas such as education and languages were seen as secondary, having an instrumental role in the internationalization process rather than being the focus of internationalization programs/plans.

UFES IO has 4 divisions currently, namely: 1) partnerships and agreements; 2) outgoing mobility; 3) incoming mobility; and 4) languages. When the former secretary resigned, both the actual secretary and the language coordinator were working at the IO in divisions 2 and 4, respectively. Because of the prominence of the division 2 (and the view of internationalization as being mostly outgoing mobility), its coordinator was invited to take the place of the former head of the office. The fact that most of the central administration at UFES comes from the STEM areas (the dean is an engineer, the vice-dean is a nurse and the provosts are engineers and physicians), had a great impact in the IO and also in the view of internationalization at UFES.

The expression "foreign institutions" suggests that UFES is using an institutional-level rationale (KNIGHT, 2005) for internationalization, in order to approach other institutions abroad, so as to enhance its international profile/reputation through strategic alliances. Yet, on a deeper look this interpretation may be misleading, for most of the partnerships made before the Capes PrInt call were based on personal/academic relationships between UFES professors and international academics.

\footnotetext{
${ }^{16}$ Science, technology, engineering and mathematics.
} 
Regarding academic mobility to foreign institutions and as previously mentioned, most of it was induced by the SwB program and so most of the outgoing mobility was done with the STEM areas at UFES. The Capes PrInt call required an institutional plan and so UFES Internationalization Policy Commission (IPC) struggled to put together isolated agreements that UFES professors had, so as to find vocations and common themes to design the UFES proposal for the call. As a result, when the PrInt call was launched, most of UFES agreements were with the STEM areas which again dominated the institutional view and proposal of IP.

One can also find evidence of the misconceptions (DE WIT, 2011b) and myths (KNIGHT, 2011) in the Internationalization Policy (IP) of UFES. For example, in the preamble of the policy, it is stated "the need of inclusion in the international context" - it could be linked to the myth of "global branding", since recognition is not the goal of an internationalization policy - it is a by-product, as stated by Knight (2011). This is restated in the expression "promoting greater visibility to UFES in the local and international scenario" which appears in the IP.

It is also stated in its IP that UFES should become an "attractive destination" - it could be linked to the myth of "international reputation as a proxy for quality". This is related to the belief that the more international a university is, the better its reputation and, consequently, its attractiveness. Later on, this is restated in the expression "promoting the quality of academic activities" in the IP. The misconception of "studying of staying abroad" is present in the expression "offer opportunities for mobility", which appears twice in the IP.

Another item to consider is "the need to diversify partners"- related to the myth of "international institutional agreements" - the greater the number of agreements, the more prestigious and attractive the institution is. It is also related to the misconception of "the more partnerships, the more international". Thus, we ask: why not developing/expanding the existing collaborations instead of signing more agreements with few impacts to the community in general? Besides, the expression "attraction of foreign students" is somehow related to the misconception "having many international students". This, in turn, in related to the misconception that internationalization equates EMI for most of the international students at UFES come from Spanish speaking countries, despite the will of the central administration to offer EMI (and not Spanish Medium Instruction) classes at graduate level. 
A positive aspect to consider in the IP is the inclusion of international and intercultural aspects in teaching, research and outreach services, going against the misconception of "no need to test intercultural and international competencies", indicated by De Wit (2011b). Moreover, by indicating "proficiency in languages" for "students, professors and administrative staff', instead of a single foreign language and a single audience, this IP seems to be multilingual and more inclusive - going against the misconception of "education in the English language" only. In practice though, what we see at UFES (and can be verified in the Brazilian EMI Guide 2018-2019) ${ }^{17}$, is that almost all of the courses/activities offered in other languages at UFES are offered in English.

Additionally, the motivations/rationales for internationalization present in the IP are the following, according to the classification by Knight (2005): development of human resources and strategic alliances (social/cultural rationales); social/cultural development and mutual understanding (political rationales); international branding/profile and quality enhancement (economic rationales); and knowledge production (academic rationale). So as to see the link between IP and LP, Figure 2 shows the most prominent words in the UFES LP.

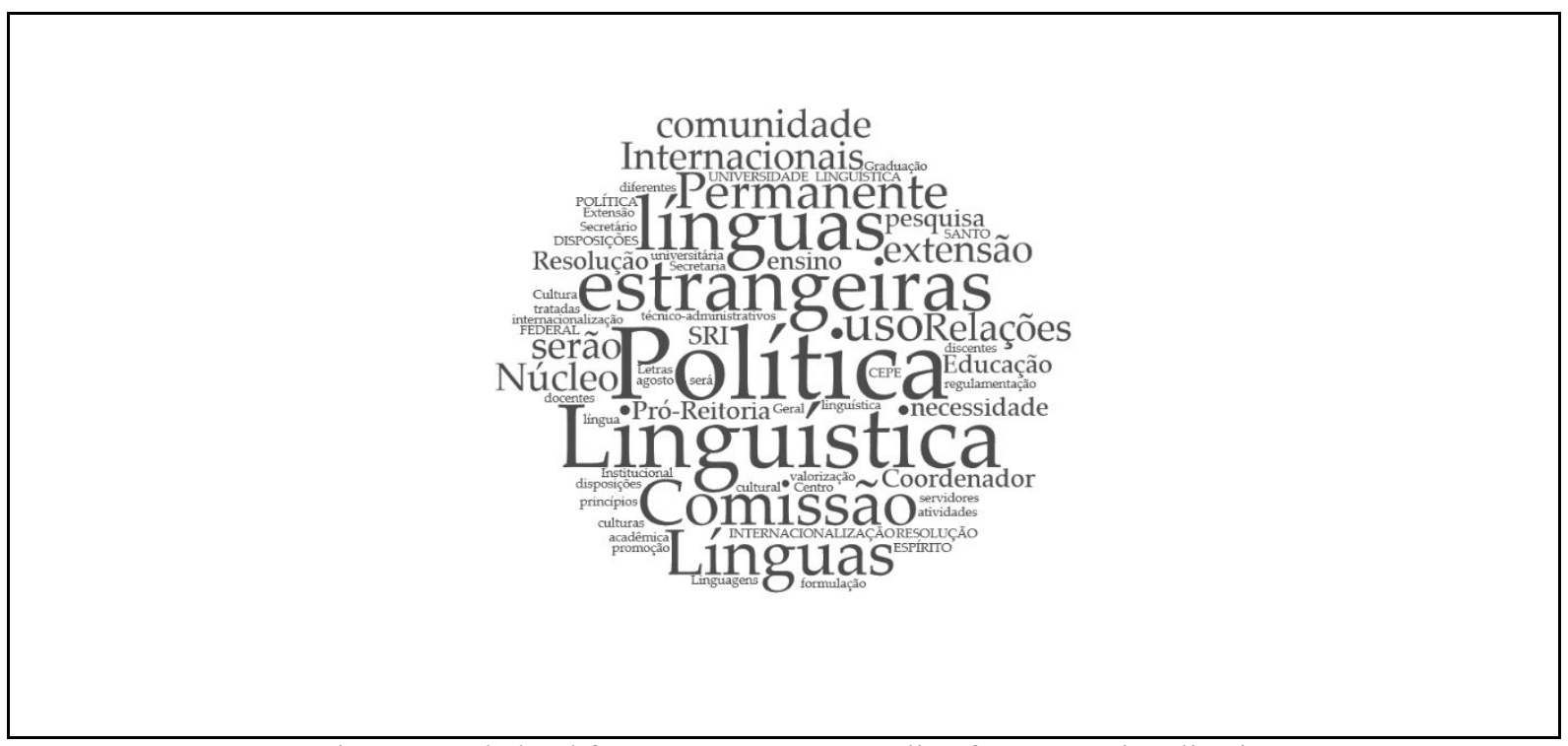

Fig. 2. Word cloud for UFES Language Policy for Internationalization

In the UFES language policy for internationalization (LP) document the words/expressions (translated here to English) that we highlight are: permanent commission;

\footnotetext{
${ }^{17}$ More information at:

https://www.britishcouncil.org.br/sites/default/files/guide_to_english_as_medium_of_instruction_2018-19.pdf
} 
foreign languages; community; outreach/services (extensão); and use. The role of the Permanent Commission for Internationalization Language Policy (PC-ILP), composed of less than 10 professors, the presidency of which is a member of the International Office (IO), is highlighted in the policy, suggesting that a wide discussion of the document within the community was not possible/desired, and that the document was approved in a top-down fashion, much like the IP and as previously suggested here.

The expression "foreign languages" suggests that other foreign languages, apart from English, may have a role in the institutional language policy. However, the fact that native/heritage languages considered minority languages used in the state of Espirito Santo such as indigenous languages (Guarani) and Pomeranian, for example, are not mentioned in the document, is evidence that the view of multilingualism and the role of languages in the internationalization process at UFES are limited to English and other majority foreign languages such as French, Italian and Spanish. Evidence of the role of these languages (specially English, French and Spanish) in the internationalization process can be seen in the languages in which the UFES website is available ${ }^{18}$.

The word "community" indicates an institutional interest to serve the academic community made up of students, professors and administrative staff. However, results of Amorim and Finardi (2017) show that the academic community at UFES does not feel engaged or included in the internationalization actions. If we contrast this result with the number representatives from students, professors and staff in the commissions that created the international plan and language policy analyzed here, we can see that indeed, the decisions and plans are made by a small group of professors (most of whom are from the STEM area) without a wide discussion (or at least hearing) of the academic community at large. This suggests that though the word "community" appears many times in the UFES LP document, it does so as an object to which the LP actions should be implemented, rather than as members that should be heard in the creation of the plans and policies.

At this point one caveat must be made. As suggested in the opening section of this paper, most HEIs in Brazil have a reactive view of internationalization. Proof of this is that most Brazilian HEIs approved their internationalization and language policies as a requirement to submit proposals for the Capes PrInt and so as to be members of IsF program, respectively. In that sense, we cannot blame UFES (alone) for hushing into the approval of

\footnotetext{
${ }^{18}$ More information at: http://www.ufes.br/
} 
these documents without wide discussion with the academic community because we suspect that what happened at UFES mirrors, to a great extent, what happened in many other institutions in Brazil.

Another word that appeared in the UFES LP cloud was "outreach" showing that UFES is concerned with creating an impact in the academic community and surrounding society. Evidence of this can be found in the offer of opportunities for developing language proficiency both for the academic community (with programs such as the LwB ${ }^{19}$ ) and the society in general through the language courses offered at the UFES Language Center ${ }^{20}$ (LC), for people who are not studying/working at UFES. The UFES LC offers courses in the following languages: English, French, Italian, German, Spanish and Portuguese as a foreign language.

The word "use" is evident in the document which aims to regulate not only the teaching/learning of foreign languages but also (and perhaps most importantly), the use of foreign languages in the institution in what concerns internationalization. Finardi and Csillagh (2016), described the use of foreign languages in the University of Geneva in six dimensions, namely: a) language of instruction; b) foreign language teaching; c) language of administration; d) language of research; e) language of external communication; and f) language of administration.

The aforementioned study was used by the Language Coordinator at UFES to propose that the UFES LP should discuss the use of languages in those six realms at UFES, too. However, since the UFES LP had to be approved quickly, so as to meet the requirements of the LwB program, there was no time to discuss the use of foreign languages in those realms with the local community, and so the document only mentioned the creation of a commission, which in turn should be in charge of regulating the use of foreign languages in those realms at UFES. However, one year after the approval of the LP at UFES, no meeting was called to discuss the use of languages in those six realms, showing, perhaps, a lack of interest of the central administration (that acts as the president of that commission in the position of the secretary of international affairs) to carry the discussion further.

Another trace of evidence of language policy at UFES can be found in the language requirement of graduate programs at UFES. Graduate programs at UFES have public calls

\footnotetext{
${ }^{19}$ UFES LwB program offers courses in English, Italian and Portuguese as a foreign language, besides the possibility to take TOEFL ITP tests and online courses. All of the LwB actions are free and offered to its academic community only.

${ }^{20}$ More information at: http://www.nucleodelinguas.ufes.br/
} 
(and some of them offer language exams) which requires candidates to prove proficiency in one additional language (for masters' courses) and in two additional languages (for doctoral courses). The use of the term "additional" language as opposed to "foreign" language was intentional here, because some graduate programs consider, for example, LIBRAS (Brazilian Sign Language) a first language and so deaf candidates can show proof of Portuguese (as an additional language) for admission, just as foreigners can show proof of Portuguese (as a foreign language).

\section{Conclusion}

Considering the analysis carried out here, we advocate for a more active (LIMA; MARANHÃO, 2009) and critical approach to internationalization, considering local values and needs before adopting foreign models that might fail in the local context. We also suggest that stakeholders in charge of creating policies and plans consider the misconceptions and myths regarding internationalization. Moreover, we suggest that stakeholders provide more room for discussion of the policies before their publication, by creating more seats for various representatives of the academic community in the commissions that create and publish such policies.

Instead of adopting top-down policies, as the ones analyzed here in the case of UFES and we suspect, in many other institutions in Brazil, and policies which are spread across the global scenario, we should consider the impact of such policies in everyday life at the campus, in order to create a policy that meets the local needs and respects local identities, being more representative of the community at large. As stated by Airey et alii. $(2015$, p.16), it is time for the perception of language policies "to change from a bureaucratic document divorced from disciplinary reality, to an important tool with something relevant to say". The same could be said for institutional internationalization plans.

\section{REFERENCES}

AIREY, John; LAURIDSEN, Karen M.; RÄSÄNEN, Anne; SALÖ, Linus; SCHWACH, Vera. The expansion of English-medium instruction in the Nordic countries: can top-down university language policies encourage bottom-up disciplinary literacy goals? The International Journal of Higher Education Research, Dordrecht, v. 73, n. 561, p. 1-20, 2015. 
AKKARI, Abdeljalil. Internacionalização das universidades contemporâneas (conferência introdutória). Comunicação pessoal. In: II CURSO DE OUTONO GCUB. Brasília, junho de 2018.

ALTBACH, Philip G.; KNIGHT, Jane. The internationalization of higher education: motivations and realities. Journal of Studies in International Education, v. 11, n. 3/4, p.290-305, 2007.

AMORIM, Gabriel Brito; FINARDI, Kyria Rebeca. Internacionalização do ensino superior e línguas estrangeiras: evidências de um estudo de caso nos níveis micro, meso e macro. Avaliação, Campinas, v. 22, n. 3, p. 614-632, 2017.

BAUMVOL, Laura Knijnil; SARMENTO, Simone. A internacionalização em casa e o uso de inglês como meio de instrução. In: BECK, Magali Sperling et alii. (Orgs.) Echoes: further reflections on language and literature. Florianópolis: EdUFSC, 2016. p. 65-82.

BERNHEIM, Carlos Tunnermann. Los desafíos de la universidad en el siglo XXI y la universidad del futuro. In: MENEGHEL, Stela Maria; CAMARGO, Murilo Silva de; SPELLER, Paulo. De Havana a Córdoba: duas décadas de educação superior na América Latina. Blumenau: Editora Nova Letra, p.241-278, 2018.

BEELEN, Jos; JONES, Elspeth. Redefining internationalization at home. In: CURAJ et al (Orgs.) The European Higher Education Area, 2015.

BERLINCK, Manoel Tosta. O método científico nos primórdios da Universidade: o caso de Andreas Vesalius de Bruxelas. Revista Ensino Superior, n.11 (outubro-dezembro), 2013. Disponível em:

$<$ https://www.revistaensinosuperior.gr.unicamp.br/artigos/o-metodo-cientifico-nos-primordio s-da-universidade-o-caso-de-andreas-vesalius-de-bruxelas $>$. Acesso em 22 de jan. de 2019.

DE WIT, Hans. Globalisation and Internationalisation of Higher Education. Revista de Universidad y Sociedad del Conocimiento, Barcelona, v. 8, n.2, p. 241-248, $2011 \mathrm{a}$.

DE WIT, Hans. Internationalization of higher education: nine misconceptions. International Higher Education, Chestnut Hill, n. 64 (Summer), p. 6-7, 2011 b.

DE WIT, Hans. Criterios para diseño y evaluación de políticas de internacionalización. Comunicação pessoal. In: CINDA: Impacto de la internacionalización sobre la calidad de la Educación Superior. Campinas, outubro de 2016.

DIAS, Marco Antonio Rodrigues. Educação Superior como bem público: perspectivas para o centenário da reforma de Córdoba. Montevideo: Asociación de Universidades de Grupo Montevideo, 2017.

FINARDI, Kyria Rebeca. Language policies and internationalisation in Brazil: the role(s) of English as an additional language. In: SCIRIHA, Lydia. (Org.). International Perspectives on Bilingualism. Newcastle upon Tyne: Cambridge Scholars Publishing, v. 1, p. 79-90, 2016a. 
FINARDI, Kyria Rebeca. Globalization and English in Brazil. In: FINARDI, Kyria Rebeca (Org.). English in Brazil: views, policies and programs. Londrina: EDUEL, v. 1, p. 15-36, 2016b.

FINARDI, Kyria Rebeca. English in Brazil: views, policies and programs. Londrina: EDUEL, v. 1, 2016c. 232p.

FINARDI, Kyria Rebeca; ARCHANJO, Renata. Washback effects of the Science without Borders, English without Borders and Languages without Borders programs in Brazilian language policies and rights. In: SIINER, Maarja; HULT, Francis M.; KUPISCH, Tanja. (Orgs.) Language policy and language acquisition planning. Springer International Publishing, 2018. p. 173-185.

FINARDI, Kyria Rebeca; CSILLAGH, Virag. Globalization and linguistic diversity in Switzerland: insights from the roles of national languages and English as a foreign language. In: GRUCZA, Sambor; OLPINSKA-SZKIELKO, Magdalena; ROMANOWSKI, Piotr. (Orgs.) Advances in understanding multilingualism: a global perspective. Frankfurt am Main: Peter Lang Edition, 2016. p. 59-79.

FINARDI, Kyria Rebeca; GUIMARÃES, Felipe Furtado. Construindo cidadania por meio da língua e da internacionalização. Revista Guará, Vitória, v. 5, n. 8, p.35-46, 2017a.

FINARDI, Kyria Rebeca; GUIMARÃES, Felipe Furtado. Internacionalização, rankings e publicações em inglês: a situação do Brasil na atualidade. Estudos em Avaliação Educacional, São Paulo, v. 28, n. 68, p. 600-626, 2017 b.

FINARDI, Kyria Rebeca; LEÃO, Roberta; PINHEIRO, Livia Melina da Silva. English in Brazil: insights from the analysis of language policies, internationalization programs and the CLIL approach. Education and Linguistics Research, v. 2, p. 54-68, 2016.

FINARDI, Kyria Rebeca; ORTIZ, Ramon Andrés. Globalization, internationalization and education: what is the connection? International E-journal of Advances in Education, v. 1, n. 1 , p. 18-25, 2015.

FINARDI, Kyria Rebeca; PORCINO, Maria Carolina. Tecnologia e metodologia no ensino de inglês: impactos da globalização e da internacionalização. Ilha do Desterro, Florianópolis, n. 66, p. 239-282, jan/jun, 2014.

FINARDI, Kyria Rebeca; SANTOS, Jane Meri; GUIMARÃES, Felipe Furtado. A relação entre línguas estrangeiras e o processo de internacionalização: evidências da coordenação de letramento de uma universidade federal. Interfaces Brasil/Canadá, Canoas, v. 16, n. 1, p. 233-255, 2016.

FINARDI, Kyria Rebeca; TYLER, Jhamille. The role of English and technology in the internationalization of education: insights from the analysis of MOOCs. In: $7^{\text {th }}$ International Conference on Education and New Learning Technologies, 2015, Barcelona. EduLearn15 proceedings, Barcelona, IATED, p. 11-18, 2015. 
GUIMARÃES, Felipe Furtado; FINARDI, Kyria. Interculturalidade, internacionalização e intercompreensão: qual a relação? Ilha do Desterro, Florianópolis, v. 71, n. 3, p. 15-37, 2018.

GUIMARÃES, Felipe Furtado; FINARDI, Kyria; CASOTTI, Janayna Bertollo Cozer. Internationalization and language policies in Brazil: what is the relation? Revista Brasileira de Linguística Aplicada, Belo Horizonte, v. 19, n. 2, p. 295-327, 2019.

HUDZIK, John K. Comprehensive internationalization: from concept to action. Washington: NAFSA, 2011.

KNIGHT, Jane. Internationalization: elements and checkpoints. Canadian Bureau for International Education, Ottawa, n. 7, 1994.

KNIGHT, Jane. Updating the definition of internationalization. International Higher Education, Boston, n. 33, p. 2-3, Fall, 2003.

KNIGHT, Jane. An internationalization model: responding to new realities and changes. In: DE WIT, Hans et alii. (Orgs.) Higher Education in Latin America: the international dimension. Washington D.C.: The World Bank, 2005, p. 1-38.

KNIGHT, Jane. Five myths about internationalization. International Higher Education, Chestnut Hill, n. 62 (Winter), p. 14-15, 2011.

LAUS, Sonia Pereira. A internacionalização da educação superior: um estudo de caso da Universidade Federal de Santa Catarina. 2012. 331p. Tese (Doutorado em Administração) -Universidade Federal da Bahia, Salvador, 2012.

LIMA, Manolita Correia; MARANHÃO, Carolina Machado Saraiva de Albuquerque. O sistema de educação superior mundial: entre a internacionalização ativa e passiva. Avaliação, Campinas, v. 14, n. 3, p. 583-610, 2009.

MARTINEZ, Ron. English as a Medium of Instruction (EMI) in Brazilian higher education: challenges and opportunities. In: FINARDI, Kyria Rebeca (Org.) English in Brazil: views, policies and programs. p. 191-228, 2016.

MENEGHEL, Stela Maria; CAMARGO, Murilo Silva de; SPELLER, Paulo. De Havana a Córdoba: duas décadas de educação superior na América Latina. Blumenau: Editora Nova Letra, 2018. Resenha de: ROBL, Fabiane. Integración y conocimiento, Núcleo de Estudios e Investigaciones en educación superior del MERCOSUR, n. 7, v. 2, p. 169-172, 2018.

MOROSINI, Marilia Costa; CORTE, Marilene Gabriel Dalla. Teses e realidades no contexto da internacionalização da educação superior no Brasil. Revista Educação em Questão, Natal, v. 56, n. 47 , p. $97-120,2018$.

REPPOLD FILHO, Alberto Reinaldo; TORRES E CARDOSO, Lisiane; VAZ, Marco Aurélio. A escola de educação física da Universidade Federal do Rio Grande do Sul e a internacionalização da Educação Superior. Movimento, Porto Alegre, v. 16, n. especial, p.217-238, 2010. 
RIBEIRO, Gustavo Ferreira. Afinal, o que a Organização Mundial do Comércio tem a ver com educação superior? Revista Brasileira de Política Internacional, Rio de Janeiro, v. 49, n.2, p. 137-156, 2006.

RICENTO, Thomas. An introduction to Language Policy: theory and method. Malden, MA: Blackwell Publishing, 2006.

SANTOS, Boaventura de Sousa. Epistemologías del sur. Utopía y praxis latinoamericana, v. 16, n. 54, 2011.

SHOHAMY, Elana. Language Policy: hidden agendas and new approaches. New York: Routledge, 2006.

SPOLSKY, Bernard. Language Policy: key topics in Sociolinguistics. Cambridge: Cambridge University Press, 2004.

STALLIVIERI, Luciane. O processo de internacionalização nas instituições de ensino superior. Caxias do Sul: [2014]. Disponível em:

$<$ http://iglu.paginas.ufsc.br/files/2014/08/SLIDES-LUCIANE.pdf $>$. Acesso em 22 de jan. de 2019.

TAQUINI, Renini; FINARDI, Kyria Rebeca; AMORIM, Gabriel Brito. English as a Medium of Instruction at Turkish State Universities. Education and Linguistics Research, v. 3, p. 35-53, 2017.

TEICHLER, Ulrich. Mutual recognition and credit transfer in Europe: experiences and problems. Journal of Studies in International Education, Newbury Park (SAGE), v.7, n.4, p.312-341, 2003.

VAVRUS, Frances; PEKOL, Amy. Critical Internationalization: moving from theory to practice. FIRE - Forum for international research in education, v.2, n.2, p. 5-21, 2015.

\section{Acknowledgement}

This study was financed in part by the Coordenação de Aperfeiçoamento de Pessoal de Nível Superior - Brasil (CAPES) - Finance Code 001. Acknowledgment Fapes (Edital Universal 03/2017).

Recebido em 29/01/2019. Aceito em 02/07/2019. 